\title{
HISTORICAL IMPORTANCE AND DOCUMENTARY ATTESTATION OF THE SALVIA SPECIES
}

\author{
Camelia Slave $\mathbf{e}^{355}$ \\ Diana Vască Zamfir ${ }^{356}$ \\ Carmen Mihaela Man ${ }^{357}$
}

https://doi.org/10.31410/itema.2018.1058

\begin{abstract}
The knowledge of medicinal plants and honey plants has been one of the most important concerns of people since the beginning of their existence. The use of plants for therapeutic purposes has been transmitted over the millennia from generation to generation, and today we are witnessing a reconsideration of the traditional medicine, in the sense that research show that herbal medicines are products more biologically accessible to human metabolism than synthetic drugs which sometimes produce side effects. The lack of scientific knowledge to explain the therapeutic qualities of these plants has long made their healing power a "mystery." Due to the progress of science, the extraction of medicinal principles from the herbs and the synthesis of new drugs have emerged.

Around the world there is a wide variety of Salvia spp. spontaneously growing plants; many of them have valuable medicinal properties while others are used for decorative purposes.

The aim of the paper is to show how this ancient plant has conquered the world with its qualities.
\end{abstract}

Keywords: Ancient times, Salvia, importance, medical principles

\section{INTRODUCTION}

alvia has been known since ancient times. The first attestation of its name (Salvia) dates back to $1400 \mathrm{BC}$, in the form of a graphic representation of the species subsequently identified as Salvia fruticosa (Greek Salvia) in a fresco from Knossos on the island of Crete. Also in the period before our era, Salvia appears in the writings of Teofrast $\left(2^{\text {nd }}\right.$ century $\mathrm{BC})$, where it is stated that its leaves were used as compresses and cataplasms for the healing of open wounds and snakes bite. [4] (Figure 1)

\footnotetext{
355, University of Agronomic Sciences and Veterinary Medicine of Bucharest 59 Mărăști Blvd, Bucharest, Romania

356 University of Agronomic Sciences and Veterinary Medicine of Bucharest, 59 Mărăşti Blvd, Bucharest, Romania

357 University of Agronomic Sciences and Veterinary Medicine of Bucharest, 59 Mărăști Blvd, Bucharest, Romania
} 
Figure 1. Crete with the isles of Corfu, Santorini and Scarpanto by G.Mercator [5]

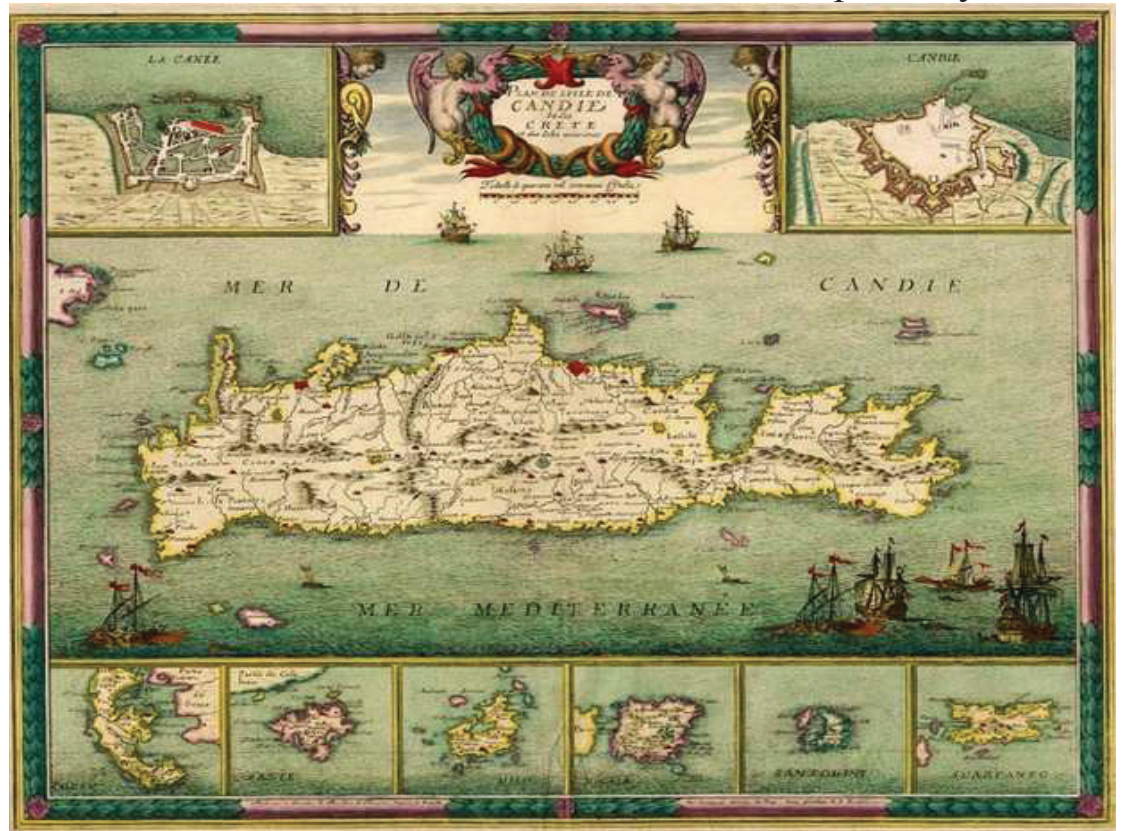

In ancient times, the name of Salvia appears in the writings of the well-known physicians of the time, Dioscorides, Galen and Pliny the Old (Naturalis Historia, $1^{\text {st }}$ century AD) and it is mainly recognized for its diuretic, anesthetic and astringent properties. When Pliny the Elder speaks for the first time about the use of the plant called Salvia by the Romans, he most probably refers to the species of the genus, Salvia officinalis. (Figure 2)

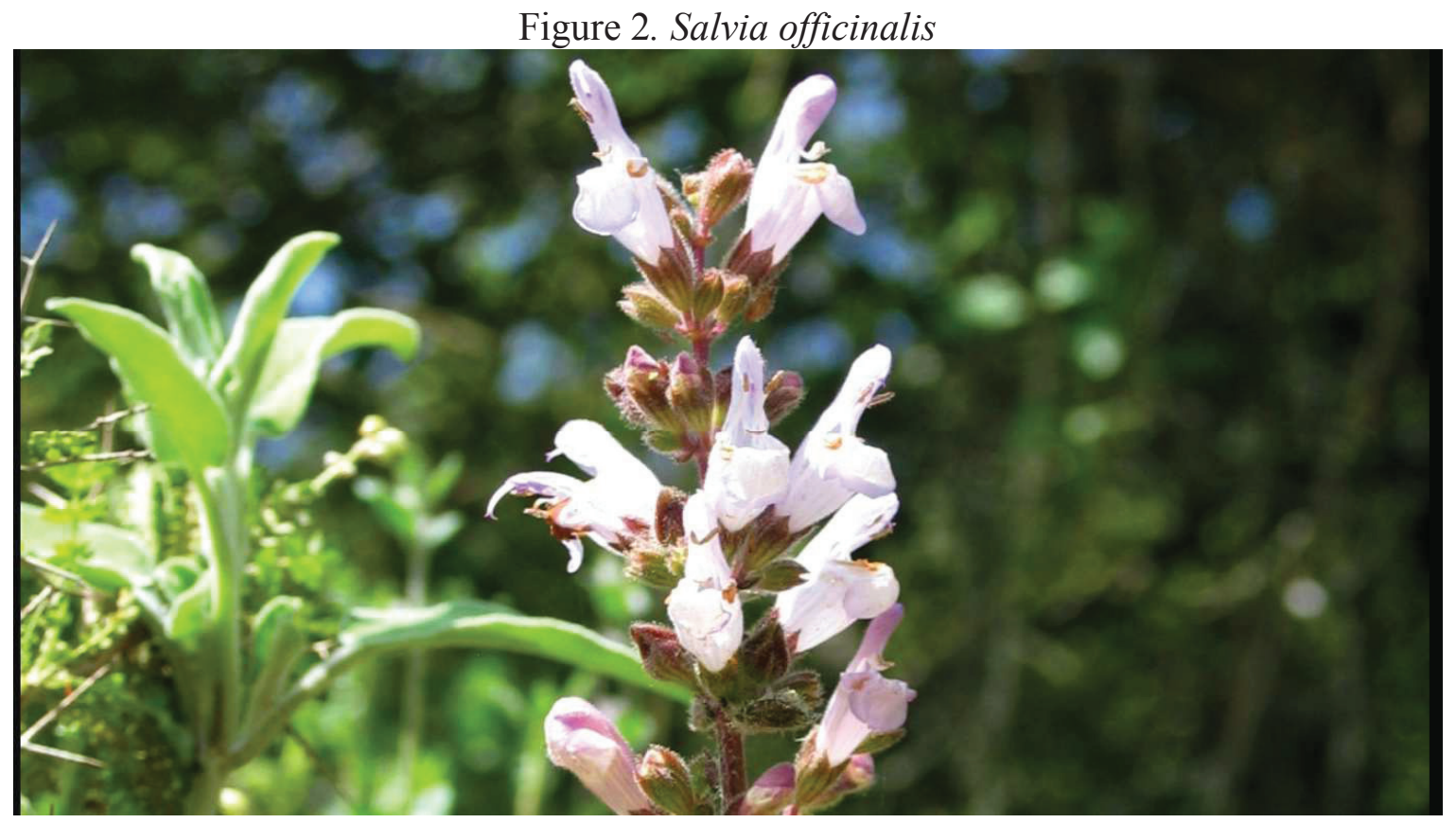

The etymology of this plant's name, originates from the Latin salvere (feeling good and healthy, health, healing), provides information about the use and recognition of the plant as a medicinal plant even before our era. 
The first to make a complete monograph of the genus was George Bentham in 1832-1836, who justified his classification on starch morphology. Bentham's work focuses on the classification of the Lamiaceae family and this is the most detailed and comprehensive classification so far.

Considered the "holy grass" by the Greeks and the "symbol of health" by the Romans, Salvia was treated with a special respect, stemming from the belief that it is a gift of Gods for men. Thus, the Romans harvested it using a special ritual: dressed in "white tunic, barefoot, and wellwashed feet" without using iron objects. At the same time, the Roman soldiers were forced to carry salvia leaves both as a medicine and for its magical protection in their food bag.

In the Middle Ages, Salvia appears in the nineteenth-century Edict, which was given by the Emperor Charles the Great, inspired by the healing monks, the most grateful herbariums, gardeners, and alchemists of the time, registering it in the list of compulsory aromatic plants to be cultivated in the imperial fields. Medieval monks used to say about salvia that it wakes up the senses, the spirit and the mind, as it "cures" it from fatigue, calms it, and illuminates it. Moreover, it heals headaches, anxiety and fear. Because it "gives the voice to the person who lost it" and has septic properties on the oral mucosa, with all of it, ulcers or infections, and all the sore throats.

Salvia was attested early in Europe due to the Benedictine monks, especially those from the Monastery of St. Gallen - Constance. (Figure 3)

Figure 3 The city of Constance [6]

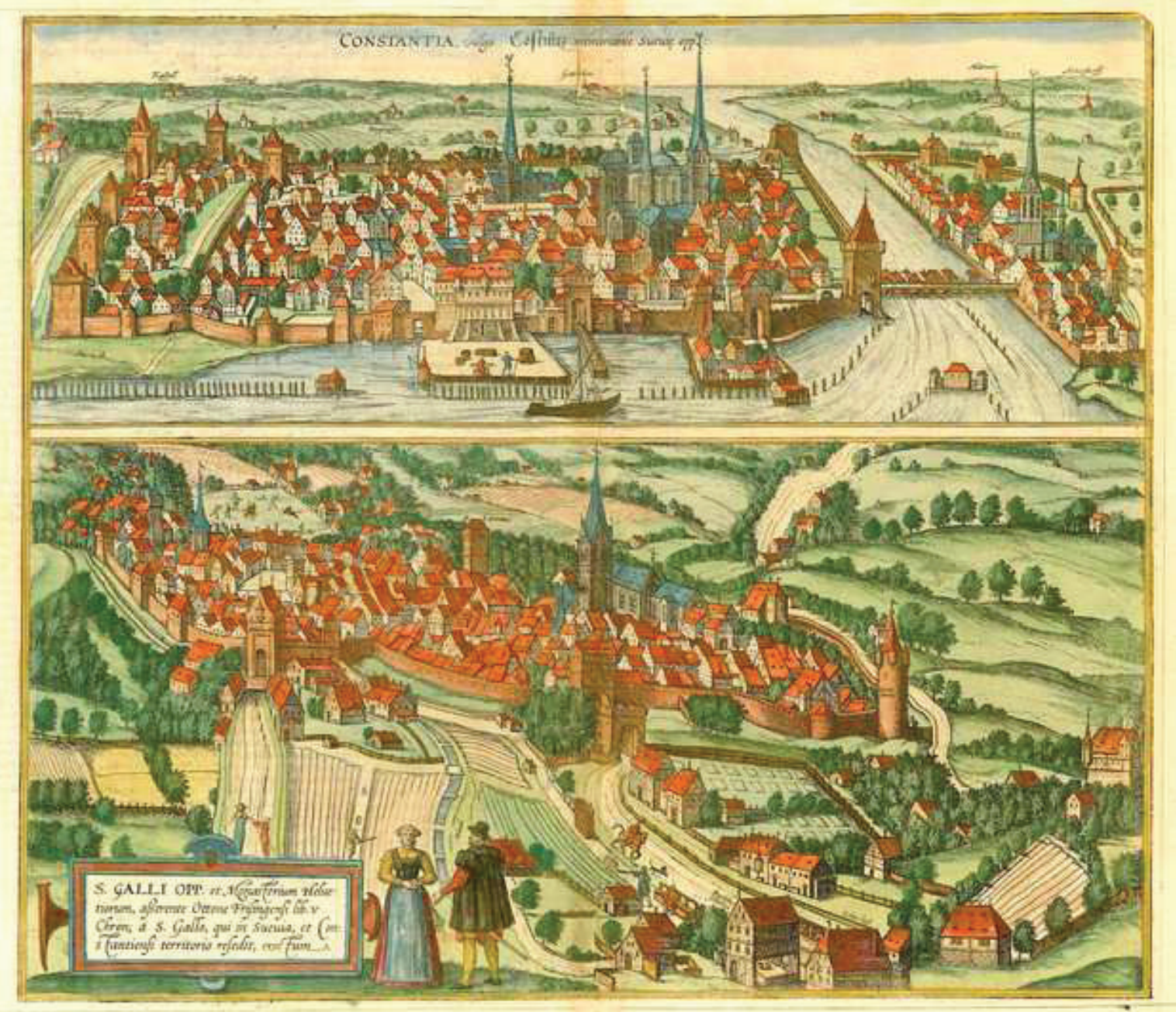


This bird's-eye view shows the city from an ideal viewpoint looking out across Lake Constance. In the 16th century it had a population of about 5,000. In the middle of the harbor is the 14thcentury building in which the conclave for the election of Pope Martin V took place during the Council of Constance in 1414-1418. On the right can be seen the originally Romanesque minster dedicated to Our Lady, which was altered in the Gothic style up to the 15th century. For over 1,000 years the show of the former bishopric of Constance was here. The second tall church tower is that of the late Gothic church of St Stephen, which the town's Parish church was. The present-day town hall is in the former guild house of the linen weavers dating from the 16th century, which does not stand out from the mass houses but which is close to the St Stephen's church. This view is made after a single - state woodcut in àœberlingen City Archives, printed by Hamma in Constance, 1544.

In the $9^{\text {th }}$ century AD, Walahfried Strabo, the Benedictine abbot of the Reichen monastery, situated on the shores of Lake Constance, praised the salvia in his poem "Hortulus" and considered it superior to all herbs:

"There, in front of everyone, the salvia shines with its sweet fragrance,

It deserves to be always green, enjoying eternal youth;

For it is full of virtues and good to mix in a cure drink

Which heals many human sufferings / diseases...!"

It is unlikely that the delicate Salvia fruticosa species could have grown in the garden of the monk Walahfried, at the foothills of the Alps, which makes us believe that the author actually referred to Salvia officinalis, which subsequently was prevalent in Germany, France, the coast of Dalmatia almost as much as in the Mediterranean: Greece, Spain, Italy and Turkey where it originates.

Also, we found out another reference to Salvia later, during the Middle Ages, also in the form of a small poem, in the Sanitary Salernitanum Regime or Regola Sanitaria Salernitana the Latin-written treaty (XII-XIII century) in the School of Medicine of Salerno (Scuola Medica Salernitana), the first Faculty of Medicine in the Middle Ages. [4]

\section{MATERIALS AND METHODS}

\section{Systematic classification}

The Salvia genus, ranked $20^{\text {th }}$ in a ranking of genus with the most floral species, belongs to the family of Lamiaceae, and comprises about 1000 species of annual and perennial plants, including bushes. Within the Lamiaceae family, Salvia is part of the Mentheae tribe of the Nepetoideae subfamily. [1]

This very prolific genus is dispersed on a very wide area, its members being lovers of sunny areas such as meadows, rocky slopes, meadows and bushes. The 1,000 species are predominantly spread in the Mediterranean and the subtropical areas (Central America, South America, and Southeastern Africa).

The ecological requirements of salvia are dictated by its Mediterranean origin; the dominant ecological factor is temperature because the plant raises when the temperature is $+10^{\circ} \mathrm{C}$.

Subsequently, the plant needs hot summer heat and mild, short winters, where the soil is covered with snow or the temperature variations are very small. For many species, late frosts, after periods of non-existent springs, can seriously destroy crops, especially if they are on bare 
ground. The land on which the salvia is planted must be protected from cold currents and dry winds, which bring dust because the dust once deposited on the irregular surface of the leaves cannot be removed. [2]

Research has shown that the way in which salvia crops are placed in the direction of cardinal points plays a very important role in plant development. Thus, according to a study conducted at the University of Agricultural Sciences and Veterinary Medicine in Banat, the quantity of salvia obtained from Eastern and Western-oriented crops was $110 \mathrm{~kg} /$ per hectare higher than in the case of Northern and Southern-oriented crops.

The species of the Salvia genus have a moderate drought tolerance, with no particular preference for humidity, but are fond of light, preferring sunny or semi-dark places (can be grown in orchards among rows). [2]

Generally, it requires fertile, deep, permeable and well-drained soils, which are slightly heated, and are rich in limestone (preferably clay-sandy chernozems). Because the Salvia species have a strong root system, they can be placed on coasts, thus having an anti-erosion role, but also on the mobile sands, thus helping to fix them. There are very few species that prefer wet and cold soils (e.g. Salvia aurita, Salvia involucrata).

\section{CULTIVATION AREAS}

In Romania, the most favorable areas for the Salvia culture are found in the southeast part of the country - In the counties of Constanta, Galati (southern), Braila, Ialomita, Ilfov, as well as in the Timis Plain and in the lower western part of the Caraş-Severin County (Craciun et ali,, 1977). In the western parts of the country, the salvia crops are welcome, as they can harness the saline soils which are unsuitable for other types of crops. [3]

Culture technology

Most Salvia species are multiplied by seeds and by cuttings. One exception is the Salvia divinorum species, which is partially sterile, in the sense that it rarely produces seeds, which are often infertile. For this species, the most viable plant breeding method is the vegetative propagation through young sprigs.

\section{CONCLUSIONS}

Since ancient times, plants have played a particularly important role in people's lives, helping to meet their basic needs.

As a partner of the human habitat, besides their biological valences, the plants possess aesthetic and spiritual valences, as they embellish not only the living environment but also the way of coexistence and expression, being the source of inspiration and artistic expression, the material of philosophical contemplations and theological.

Even if we are moving fast towards an era of technology, being assaulted every day by the spectacular achievements of technology, increasingly advanced devices, nanotechnologies that predict a lasting breakthrough in medical science or global communication, plants and flowers, remain indispensable to people's lives, as in the past undeniably important in our lives. 
The biodiversity of the Salvia genus is directly proportional to the ability to adapt the species of this genus to the most diverse environmental conditions. Having a very good environmental plasticity, the members of the genus have a vast diversity of stamen structure, vegetative port and of flower morphology.

Showing not only many similarities between species but also many varieties with specific characteristics, the number of species and subspecies of Salvia that are named and described exceeded 2000 (2559 plant names are listed in Plant List.org), of which 1045 names are synonyms of the 1037 species accepted. A modern comprehensive study reduced the actual Salvia genus count to 700 distinct species belonging to both the Old World (Europe and Asia) and the New World (North and South America).

Being cultivated since ancient times all over the world for medicinal, culinary and ornamental purposes, Salvia species still enjoy special attention today thanks to its many curative properties (Salvia officinalis, Salvia nemorosa) and to its the special flavor (Salvia elegans, Salvia sclarea, Salvia dorisiana).

These properties consist of volatile oils contained in the leaves, due to the special nutritive content of the seeds (Salvia hispanica). Also, its huge aesthetic and decorative potential is considered by landscapers who impose trends in ornamental plants.

Thus, whether they are in the form of grassy, annual or perennial plants, or in the form of bush, sometimes tall, richly grown from the base, and sometimes small and compact in appearance, the Salvia plants give the space in which they are placed a plus of variety and color through the palette of flower tones and the foliage coloring.

The specific epiteth, officinalis, attests the medicinal use of the plant, since in Latin the officina refers to the monasteries in which the medicinal plants and the medicines obtained from them were kept.

Due to the complex chemical composition of its volatile oil and other active principles, the leaves have carminative, antiseptic, bacteriostatic properties and pronounced antisudoric action. Salvia is a light hypothermic agent.

The incredible diversity of the genus and its great ability to adapt to drought conditions of the species recommend Salvia for successful use in rustic gardens, natural and wild landscapes as well as in aromatic ornamental gardens.

Through all its qualities, sometimes reunited under the umbrella of a single species, sometimes representing the defining characteristic of certain species, the Salvia genus is a true treasure of nature, generously made available to people, which should enjoy their special attention and appreciation.

\section{REFERENCES}

[1] Bojor O. (2003) Ghidul plantelor medicinale şi aromatice de la A la Z, Editura Fiat Lux, Bucureşti, p.204-205.

[2] Crăciun F., Bojor O., Alexan M., (1977). Farmacia naturii, Editura Ceres, Bucureşti, vol. II. p 88-95 
[3] Ciocârlan V., (2000). Flora ilustrată a României- Pteridophyta et Spermatophyta. Editura Ceres, Bucureşti, p.647-678

[4] Staub J. (2008). 75 Exceptional Herbs. Gibbs Smith Publishing House, Layton. P.201

[5] https://www.sanderusmaps.com/en/our-catalogue/detail/164006/old-antique-map-ofcrete-greek-islands-by-mercator-hondius

[6] https://www.sanderusmaps.com/en/our-catalogue/detail/162117/\%20antique-map-ofconstance-(konstanz)-sankt-gallen-by-braun--hogenberg/ 